\title{
FULFILMENT OF AUGUST ANTONIUS RAUBER'S LONG-TIME DREAM
}

\author{
Maie Toomsalu \\ Department of Anatomy, University of Tartu, Tartu, Estonia
}

\begin{abstract}
In his educational work, August Antonius Rauber, professor of Anatomy of the University of Dorpat (nowadays the University of Tartu) paid great attention to improving students' training. He expected the educational museum of anatomy to be of great help in this. He began arranging it immediately after his arrival in Tartu in 1886. Professor Rauber lectured in German, but the number of Russian students was increasing rapidly in that period. Their command of German was limited - therefore, illustration of lectures with models and original specimens was of great significance. The museum opened in 1890 and found great recognition because of the quality of its specimens, originality of models and general organisation. Part of the exhibits of the educational museum of anatomy have been preserved to the present, and they are displayed at the exhibition of the Medical Collections of the Faculty of Medicine and are used in everyday work of the Department of Anatomy.
\end{abstract}

Keywords: educational museum; dry specimen; wet specimen; dry glycerine specimen; skeleton; models; exhibition

\section{A PROGRESSIVE IDEA}

In 1885, Professor of Anatomy Ludwig Stieda left the University of Dorpat (Tartu) for the University of Königsberg, and the post of the professor of anatomy in Dorpat remained vacant. On 18 November, Professor of Ophthalmology Eduard Raehlmann made a proposal to August Rauber to come to Dorpat as an ordinary professor of anatomy. The University of Dorpat had a good reputation, and several well-known scientists like Alexander Schmidt, Richard Thoma, Heinrich Max Runge and Emil Kraepelin were working there. 
At that time, the University of Dorpat was a university with German scientists, German spiritual life and a numerous Germanspeaking student body, and August Rauber accepted the offer.

He arrived in Dorpat on 21 February 1886 after being elected to the post of Ordinary Professor of Anatomy. On 27 February 1886 he took his oath of office and delivered the introductory lecture "On the significance of scientific anatomy". Rauber had always considered illustration of lectures important and, therefore, he brought along three boxes of wet specimens, a box of anatomical specimens and plaster casts,

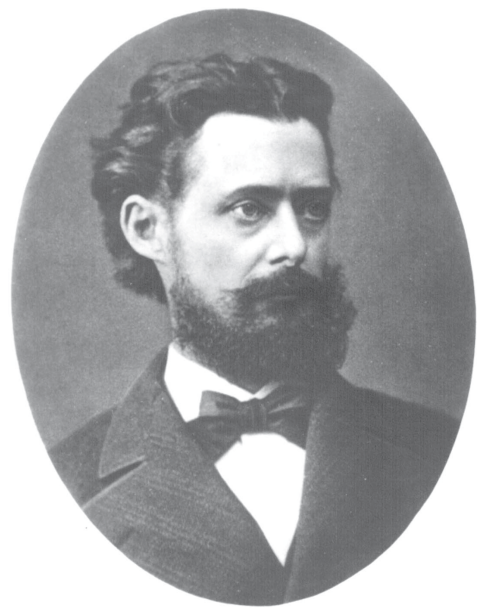

Figure 1. August Antonius Rauber, 1870. (University of Tartu Museum). and a box of models of prehistoric tools. In Dorpat, A. Rauber also paid great attention to the improvement of students' training, attaching particular importance to the educational museum. He began arranging it immediately after his arrival in Tartu. Professor Rauber (Fig. 1) lectured in German, but a great number of his students were Russians whose command of German and general knowledge were poor. Therefore, the illustration of lectures with models and original specimens was of particular importance. His predecessor L. Stieda had left behind more than 800 specimens and models; Rauber himself was very skilful at anatomical preparation and also trained his technician Alexander Reinwald. Rauber procured German models and made metal casts for teaching of bones and wooden models for teaching of joints. Many of the exhibits were the handiwork of his technician A. Reinwald. Eventually, the museum grew so big that it took up nearly the whole ground floor in the left wing of the Old Anatomical Theatre. Comprehensive models and excellent specimens were displayed in beautiful showcases. The museum opened in 1890 and found great recognition because of the quality of its specimens, originality of models and good general organisation $[1,3,4]$.

\section{WHY WAS THE STUDIENSAAL NEEDED?}

In 1895, A. Rauber published the paper Über die Einrichtung von Studiensälen in anatomischen Instituten (Fig. 2). In its introductory part, Rauber gives the 
ther die

\section{Finniohtung yon Studiensälen}

anatomischen Instituten.

Yon

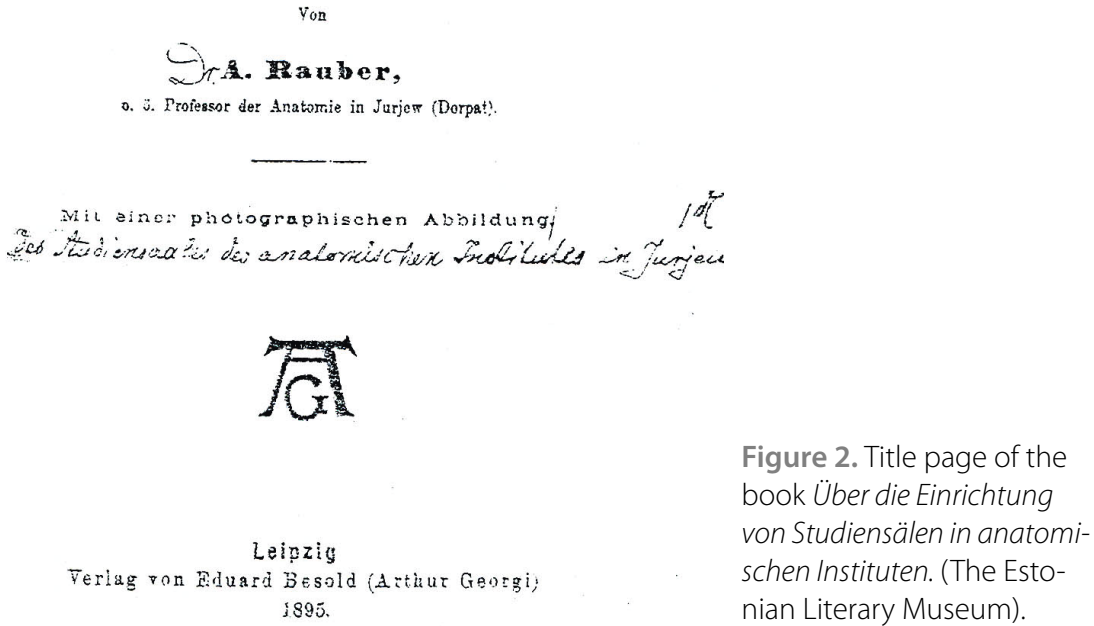

history of the foundation of the Studiensaal (hall of studies). He writes that usually institutes of anatomy have at least four rooms for studies: a lecture room, a room for collections, a preparation hall and a microscope hall.

Rauber, however, wants to emphasise the significance of the fifth main room. When the Institutes of Physiology and Pathological Anatomy moved to the New Anatomical Theatre in 1890, many rooms remained vacant for the Institute of Anatomy, and Rauber used them to establish the educational museum (Fig. 3). He writes: "Seitdem führt dieser Studiensaal ein fröhliches, nie unterbrochenes Dasein, hat sich in der Studentenschaft fest eingebürgert und wird voraussichtlich in Zukunft nicht wieder von der Bildfläche verschwinden" [2]. (From that time onwards, joyful, uninterrupted life is going on in the hall of studies; it has found its fixed place among the students and is not likely to disappear from the horizon in the future.) Rauber also mentions that actually the story of the educational museum began much earlier; he had the idea in the early 1880s already, and actually it could even go back to the time of his studies at the University of Munich. Rauber describes: „Die grossen, reichbesetzten Sammlungsräume des anatomischen Institutes, an welchen ich meine 
Lehrjahre verbrachte und meine erste Anstellung erhielt, hatten gerade durch ihren Reichtum, aber auch durch die unumgänglich notwendige Abgeschlossenheit ihrer Schätze es mir angethan. In der Folge trat der bezügliche Wunsch gelegentlich stärker hervor. Endlich gelangte er hier in Jurjew zur Erfüllung" [2] (The large, richly filled collection rooms where I spent the years of my studies and got my first workplace appealed to me namely by their richness but also by the inevitably necessary seclusion of their treasures. Later, this wish became stronger now and again. It was finally fulfilled here, in Yuryev.) (Dorpat was named Yuryev in 1893 because of the Russification policy.) Rauber's imagination of the educational museum was that it should be a room with a great number of original specimens, plaster casts, models and wall charts covering the whole area of anatomy so that the students could learn from them. For this purpose, all the items are displayed so that their details are clearly visible; most of them are on tables covered by glass boxes so that they could be safely demonstrated during teaching and protected from inevitable damage. The room of collections meant for anatomy lectures with its much richer content will not be included in the educational museum. In the exhibition hall, there are rows of tables with exhibits; at them, in some cases around the table, there are simple long wooden benches so that students could comfortably study the exhibits with the help of a textbook or without. To keep the rooms of the educational museum open in winter, it is well heated so that the visitor always finds

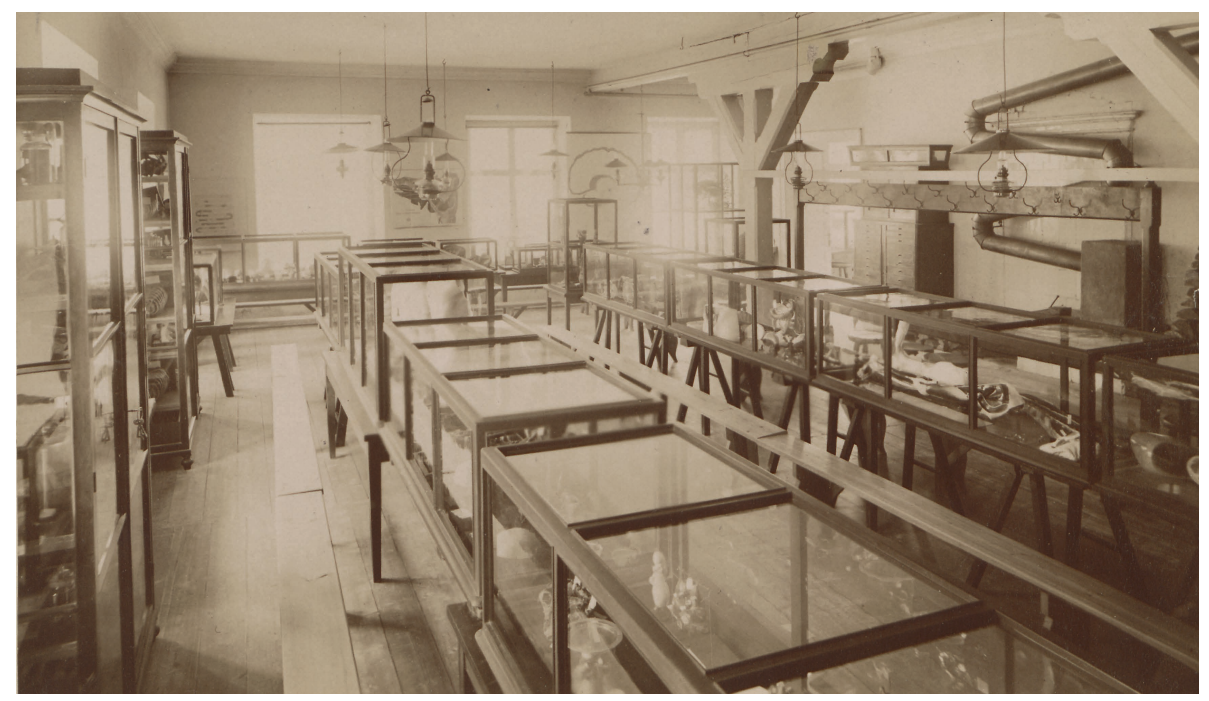

Figure 3. Anatomical museum in the left wing of the Old Anatomical Theatre. (From the book "Über die Einrichtung von Studiensälen in anatomischen Instituten“. Photo: Bayerische Staatsbibliothek). 
a pleasant temperature and is even therefore attracted to the hall. The same also concerns the lighting. Hanging lamps should be installed and chandeliers above the most essential objects so that the lighting would leave nothing to be desired even on dark afternoons. For a later time, the use of electric light is planned. Smoking is forbidden. The educational museum is not meant for medical students only but also for students of all faculties; neither is entrance forbidden for doctors and other educated people. The educational museum has an assistant or servant who acts as a supervisor. On two days a week, the assistant on duty demonstrates the most essential objects one after another. At the cash-desk a small, fixed sum is registered and paid; the income is used to cover the expenses of the educational museum and to procure new items. A. Rauber found that the museum should give students all the opportunities for learning anatomical details, instil in them respect for anatomy as a science and give them an understanding of the scope of the discipline. The Tartu museum of anatomy served as a model for new analogous museums. Rauber himself had visited several other educational museums of anatomy, for example Vesalianum in Basel, and acquainted himself with the rich collections of anatomical specimens in Munich and Leipzig [4].

\section{ON THE SIGNIFICANCE OF THE EDUCATIONAL MUSEUM OF ANATOMY}

Rauber has written the following about the significance of the educational museum: "Even the first impression of the hall is of essential educational value for the young medic. It could be very well compared to the influence of the art museum on a young, receptive soul which surpasses a certain limit where the scientific influence prevails according to the nature of the exhibits. The first impression is festive, elevated and much more powerful than the first-year student expects. Even the unexpectedness of the view has a favourable influence. Many are so greatly overwhelmed by the richness of the material that some time is needed to reach understanding. Thus, even the first impression is of great value for the new student and makes an excellent beginning.

The further efficiency of the study hall is caused by other essential influences. The good consequences of extreme visualisations come forward sooner or later. The initially constricted and shy student will learn to see, differentiate and to decide more exactly. He can stay at each object as long and return to it as frequently as he wants, until he has finally achieved the victory; these objects constantly serve as examples according to which he can arrange his work in the preparation hall. So, the hall of studies partly prepares for understanding the 
lectures and the numerous specimens displayed here, partly for the preparation hall; it simultaneously enables many things that were mentioned in the lecture in passing to have a sufficiently long influence. In the later semesters, when the lectures of anatomy have already finished, the educational museum proves its necessity again. During the clinical semesters, the student often notices the endless tangible practical value of anatomy.... the anatomical knowledge that has been acquired with difficulty fades too quickly or disappears completely if one does not constantly work on consolidation of the material. Here, the educational museum offers endless opportunities for avoiding this threat" [4].

Until now, Rauber brought forth the significance of the hall of studies for medical students, but "the hall of studies where the scary side is entirely absent is also appropriate for students of other faculties to provide them with knowledge about their bodies through visualised instruction. If such study halls are able to exert their favourable influence and encourage non-medics to study anatomy, this is, in my opinion, a sufficiently great achievement to justify their establishment at institutes of anatomy in the future." He also adds that "... not each institute of anatomy has enough room to accommodate such a study hall, although they would like to, but where there is room for it, it should be urgently recommended to use it for that purpose" [4].

In his publication Über die Einrichtung von Studiensälen in anatomischen Instituten, Rauber provides a list of exhibits of the whole educational museum according to tables, adding also the windowsills and the bone closet. The room had 16 tables with display cases, 5 windowsills, 2 skeletons and, additionally, 28 wall charts [2].

In the following, an attempt is made to create a visual picture of the educational museum as it was in Rauber's times.

The tables were covered with large glass boxes fastened by screws. A few exhibits were placed on suitable stands. The exhibits included macroscopic anatomical dry specimens of the heart; two of them were specimens of the new-born's heart. There were also dry and wet specimens of arteries and veins. A coloured plaster model showed the chest and abdominal cavity with heart, diaphragm, spleen, kidneys, pancreas and duodenum. Another coloured plaster model depicted the head and the neck. On one of the tables, two coloured plaster models made by His, one by Kronecker and one by Solger were displayed. There were several models of the brain by Steger and Flechsig, a wet specimen of the brain and a paper model with pathways shown on the crosssection of the spinal cord. Another model of spinal cord pathways had been made by Edinger. A number of specimens, casts and models depicted the orbita 
and visual organs. As for the hearing organs, there was a large model of the bony labyrinth of the ear by Dursy-Froriep and many specimens, models and casts. There was a coloured plaster model by His of the human internal organs with the vertebral column and the pelvis. Several coloured plaster casts showed the surface muscles of the upper and lower extremities and the deep muscles of the leg and the foot. Several plaster casts of internal organs had been made by Braune, His and Rauber. Plaster models by Braune showed the horizontal, frontal and diagonal frontal sections of the chest and abdominal region and one plaster model of the lungs, pleura and diaphragm. Rauber had also made plaster models of muscles and a plaster model of the liver under the diaphragm. Cross-sections of frozen upper and lower extremities were the work of Pansch.

A curious fact is that the model of the brain and spinal cord pathways on table 9 was stolen by students in the 1890/91 academic year.

Many exhibits were displayed on the windowsills. There were dry glycerine specimens of body ligaments in a glass box, spirit specimens of the brain, the spinal cord and the hearing organs.

The museum also had wall charts with valuable anatomical drawings in the rooms. Unfortunately, none of the anatomical charts have preserved.

The large open bone closet contained 58 bone specimens. Each individual bone or complex of bones was attached to a stand and numbered; at each bone, there was an explanatory label in a glass frame. Individual exhibits could be taken out of the closet if desired and placed back after examining them.

For studies of the skeletal system, there were two skeletons in the hall [4].

\section{THE CURRENT DISPLAY OF THE MEDICAL COLLECTIONS HAS GROWN OUT OF THE EDUCATIONAL MUSEUM}

Unfortunately, a great deal of the Tartu anatomy museum and A. Rauber's painstaking work has been destroyed in wars and political whirlwinds, but luckily not everything. Even today, a few dozens of Rauber's original specimens and models can be seen at the anatomy exhibition in the preparation hall of Biomedicum (building of the Faculty of Medicine of the University of Tartu) and at the exhibition of medical collections in the Science Centre AHHAA.

Rauber was lucky to get rooms for his museum in the glorious Old Anatomical Theatre. The present collection of medical exhibits, which includes exhibits on anatomy and pathological anatomy, has no place where to arrange a permanent exhibition with up-to-date design and the necessary technical aids. Because of intrigues caused by the smallness of Estonia, the medical collections 
lack state financing, as they are not considered a museum. Until now, sums from selling books and souvenirs have been used to upgrade the exhibition, but from 1 September 2021, this opportunity will partly disappear. For the next five years, the exhibition of the medical collections will remain at the AHHAA Science Centre (Fig. 4). As August Rauber dreamed, anatomy is also of interest for students of other faculties, townspeople, guests from near and far.

The time has changed; people are catching the Covid-19 virus; they suffer and die because of it. This has also changed the current visitors of the medical display. The exhibition has been updated with a showcase on this viral disease. Visitors from Latvia, Bolivia, the UK, Australia, the Argentine, Japan and

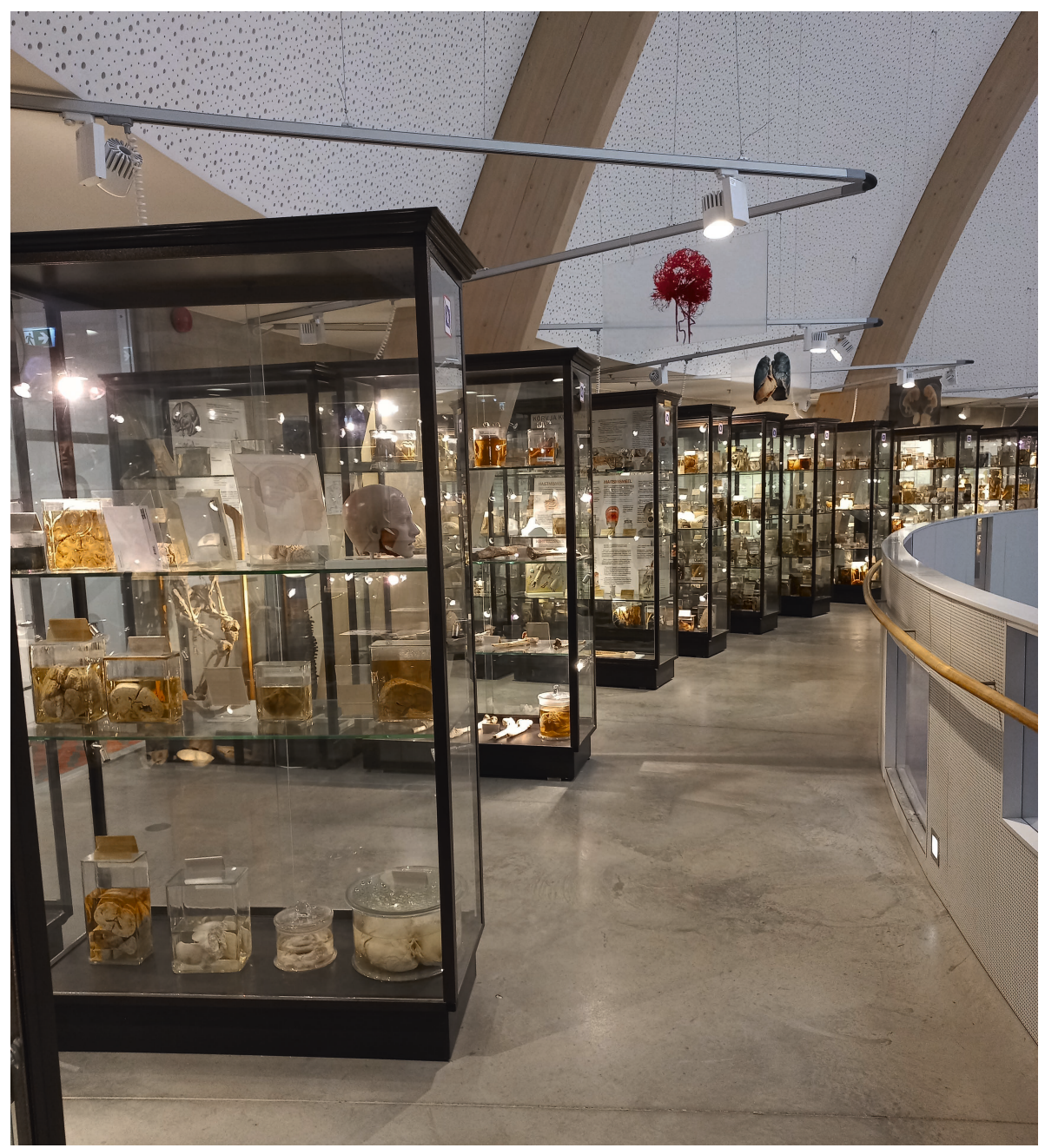

Figure 4. General view of the showcases of the Medical Collections. Photo by Maie Toomsalu. 
many other countries read and look, think, ask for advice and tell their stories. Sometimes they have to walk around in masks, sometimes without. Hand disinfectant bottles get empty quickly, as people are taking greater care of their health. People understand that because of the spread of the disease they cannot have fun with some interactive exhibits. They often ask for the staff's opinion about vaccination and whether the staff members have been vaccinated. People from neighbouring countries ask where they can be vaccinated in Estonia. The exhibition is so crowded that it is difficult to move around. This shows that the exhibition is necessary for people; it should be much larger and better to view. It can only be expected that the administration of the University of Tartu understands it and finds a real and permanent home for this historical gem.

\section{CONCLUSION}

This year, the University of Tartu and the town of Tartu celebrated August Rauber's 180th birth anniversary. On this occasion, the medical collections opened a small display of exhibits that originate from A. Rauber's educational museum. Television was present and the exhibition was shown to the whole country. Newspapers wrote that Rauber's idea is alive and the textbook related to his name is still used to learn anatomy. Even today, people take photos of

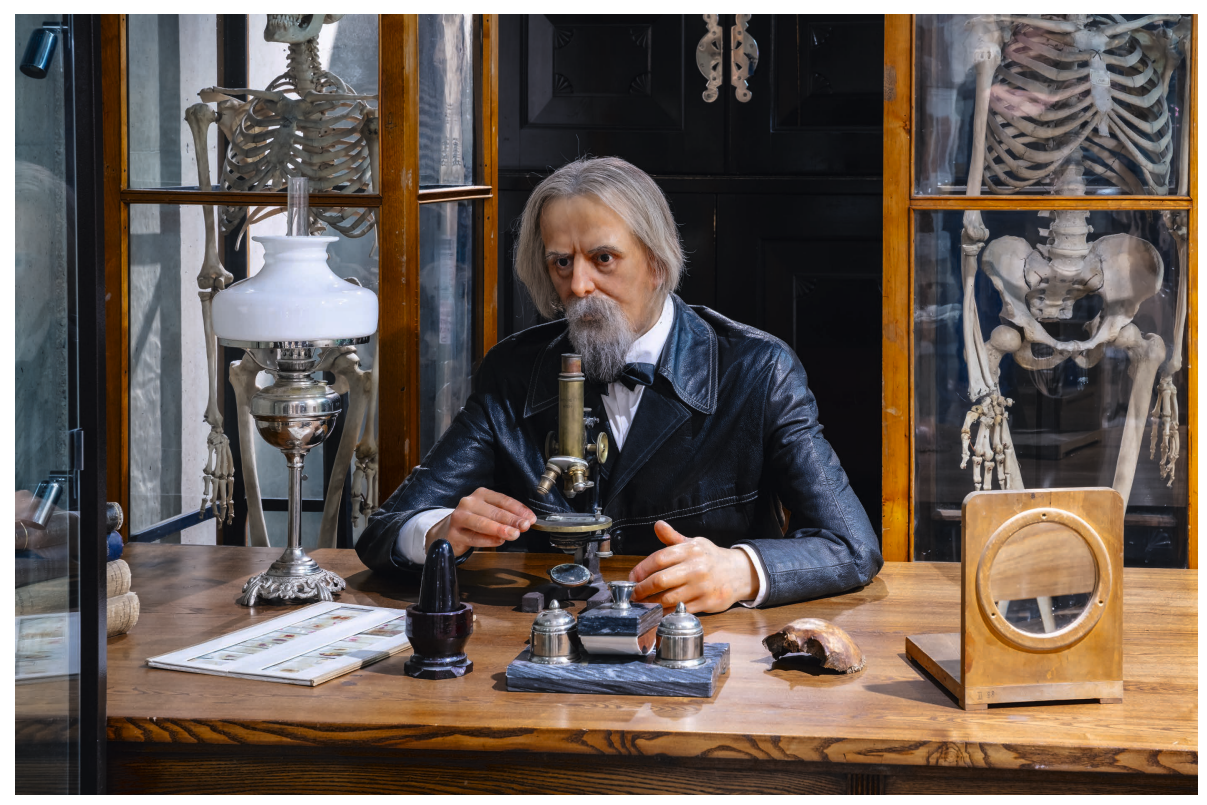

Figure 5. August Antonius Rauber's wax figure. Photo by Andres Tennus. 
themselves in front of Rauber's wax figure to be in the picture together with the celebrity (Fig. 5). They carefully watch the slide programme about Rauber and his famous educational museum.

We can also see that people are interested in the medical exhibition and they visit it repeatedly. It is necessary for educating both children and adults regardless of their nationality. This is an exhibition for the whole world.

I am of the opinion that Rauber would only be satisfied if the museum of medicine were accommodated at a worthy place on the premises of the University of Tartu, not as a poor relation on the gallery of the Science Centre. The complicated times and the rapidly mutating Covid-19 virus have made people think more about their health. It would be wonderful if, instead of dilettante bloggers, senior students of medicine, using medical specimens and models, could explain to people how to fight the disease.

\title{
REFERENCES
}

1. Põldoja, E., Simovart H.-E., Kokk, K., Kolts, I. (2005) Professor August Rauber ja anatoomia õppemuuseum. Tartu Ülikooli Ajaloo Küsimusi, XXXIV, 200 aastat Vana-Anatoomikumi, Tartu: Tartu Ülikooli Kirjastus.

2. Rauber, A. (1895) Über die Einrichtung von Studiensälen in anatomischen Instituten. Mit einer photographischen Abbildung. Leipzig: Verlag von Eduard Besold (Arthur Georgi).

3. Toomsalu, M. (2009) Anatoomiaprofessor August Antonius Rauber. Tartu: Tartu Ülikooli Multimeediakeskus.

4. Toomsalu, M. (2020) The Legend is alive: August Antonius Rauber. Professor of Anatomy. Tartu: Atlex.

\section{Address for correspondence:}

\author{
Maie Toomsalu \\ Department of Anatomy \\ University of Tartu \\ Ravila Street 19, 50441, Tartu, Estonia \\ Email:maie.toomsalu@ut.ee
}

